\title{
Research Support In Policy Formulation At The Border Management Agency Of North Central Timor District
}

\author{
Yohanes Fritantus ${ }^{1}$, Makarius Erwin Bria ${ }^{2}$ \\ State Administration Program, University of Timor ${ }^{1}$ \\ Governmental Science Program, University of Timor ${ }^{2}$ \\ Email: yfritantus@gmail.com ${ }^{1}$ \\ Email: erwinbria@gmail.com ${ }^{2}$
}

(Received: May 17-2020; revised: Juny 10-2020; published: December 31-2020)

\begin{abstract}
The research objectives were (1) to analyze and describe the role of research in the formulation of border management policies in the Regional Border Management Agency of North Central Timor Regency; (2) Analyze the challenges of utilizing research results by the Regional Border Management Agency of the North Central Timor Regency. The research approach used is descriptive qualitative research methods. Determination of sampling using snowball sampling, which is the activity of collecting information continuously until the information feels saturated. Furthermore, data were collected using an in-depth interview, observation, and documentation. The results obtained are that first, the role of research in the formulation of border management policies in the Border Management Agency is to identify strategic issues related to border management in North Central Timor Regency. Second, the challenges of utilizing research results in the formulation of policies by the Regional Border Management Agency of North Central Timor Regency include a) constraints on the limited quantity of human resources of the TTU Regency Regional Border Management Agency; b) communication of research in the form of policy advocacy is not optimal.
\end{abstract}

Keywords: Policy Formulation, Research Results, Border Management

\section{INTRODUCTION}

Geopolitically, East Nusa Tenggara Province and North Central Timor Regency are land borders with Timor Leste, namely the Oecussi District. As the front porch of the country, the development of human resources and infrastructure should be considered and repaired. Therefore, the attention of the Central Government and Regional Governments, the community, and all interest groups is devoted to the development of better border areas.

In an effort to support the acceleration of the development of the border area in the North Central Timor Regency, a regional apparatus body / organization that specifically manages the border was formed. In the North Central Timor Regent Regulation Number 3 of 2019 concerning the Establishment of the Regional Border Management Agency of North Central Timor Regency and the regulations above, including the Regulation of the Minister of Home Affairs of the Republic of Indonesia number 140 of 2017 concerning the formation of the Regional Border Management Agency mandating the Regional Border Management Agency to prepare plans actions, programs and development budgets for border border areas in accordance with the priority scale. 


\author{
320 | Jurnal Ilmiah Ilmu Administrasi Publik: Jurnal Pemikiran dan Penelitian Administrasi \\ Publik \\ Volume 10 Number 2, July-December 2020. Page 319-330
}

In general, producing a quality policy is strongly influenced by various factors, including the support of quality researches. According to Sumarto, S. (2018), evidence of research results must always be used as a basis for policy making. This is the ideal condition expected in the public policy decision-making process. However, in the fact that, there are still gaps or nonideal conditions, namely research is often irrelevant to the needs of public policies, very limited access to research results, policy makers complain about the difficulty of accessing and understanding research results when needed to be used as a basis for taking Policy.

The results of in-depth studies and research can support quality policy making. Research is basically a scientific way of obtaining data for specific purposes and benefits. This means that research activities are based on scientific characteristics, namely rational, empirical and systematic. Research is an academic and scientific activity that is intended to find solutions to problems that occur with certain data criteria / conditions. In the Regulation of the Minister of Research, Technology and Higher Education Number 20 of 2008 concerning Research, (article 1) research is an activity carried out according to scientific principles and methods systematically to obtain information, data and information relating to understanding and proving the truth or untruth of a assumptions and / or hypotheses in the field of science and technology and draw scientific conclusions for the purposes of advancing science and / or technology.

According to Dye (In Jones, C; 1994)), political policy is the government's choice, whether to do something or not to do it. This is also supported by Anderson's statement (In Wahab, S. A; 2014), namely that public policy is a series of actions that have goals that are followed and carried out by individuals or groups to solve a problem. In the public policy cycle, before a policy is implemented, the policy must be well formulated. According to Dunn (in Sadhana, K.; 2011) defines the policy analysis process as a series of political activity / activity processes that are visualized in a series of stages, including the stages of agenda setting, policy formulation, adopting a policy, implementing policies, and assessing / evaluating policies.

In discussing the formulation of a public policy, the following stages are first, formulating the problem (Defining-Problem), which is the most fundamental stage for identifying, formulating and defining the problem well. The second stage, the Policy Agenda, is the stage where a problem that has been identified and meets certain requirements such as the extent or absence of the impact of a problem will be included in the policy agenda so that it can be discussed by policy makers. Third, Alternative Selection 'Policy as Solution to a Problem, namely the stage where policy makers are faced with alternative policy choices for solving a problem. And the fourth stage, namely the stage for determining a policy that has been chosen so that it has binding legal force.

Previously, the definition and stages in policy formulation have been explained. Public policy can be classified into several levels (see table 1). The level / classification of this policy can be influenced by studies. 
Table 1. Classification Policy

\begin{tabular}{clcl}
\hline Category & \multicolumn{1}{c}{ Lomas } & Hanney, S.R. & \multicolumn{1}{c}{ Black } \\
\hline 1 & $\begin{array}{l}\text { Legislative Policies: relate to } \\
\text { the overall framework for } \\
\text { organizing health service }\end{array}$ & National Policies & $\begin{array}{l}\text { Governance Policies: } \\
\text { relate to organizational } \\
\text { and financial structure }\end{array}$ \\
\hline 2 & $\begin{array}{l}\text { Administrative Policies: } \\
\text { relate to the running of } \\
\text { services and allocation of } \\
\text { resources within the overall } \\
\text { framework }\end{array}$ & $\begin{array}{c}\text { Local Health Service } \\
\text { Policies }\end{array}$ & $\begin{array}{l}\text { Service policies: covers } \\
\text { resources allocation } \\
\text { issues and pattern of } \\
\text { services }\end{array}$ \\
\hline 3 & $\begin{array}{l}\text { Clinical Policies: what } \\
\text { therapies are applied }\end{array}$ & Policies made by \\
& & professional bodies & $\begin{array}{l}\text { Practice policies: the use } \\
\text { of resources by } \\
\text { practitioner in delivering } \\
\text { patient care }\end{array}$ \\
\hline
\end{tabular}

Source: Hanney,S.R (Dalam Sundari, S.; 2007)

Based on the opinions of the experts above, in general, the classification of policies can be explained as follows:

1. Strategic policies / public policies are in the form of Regional Regulations and the implementer is the Regional Head together with the DPRD;

2. Managerial policies which are manifested in the form of Regional Head Regulations, Regional Head Decrees and the perpetrators, namely Regional Heads (Governors, Regents and Mayors);

3. Technical policies embodied in the form of SKPD, Policy and Program Decrees, as well as the actors, namely the Head of SKPD (Agency, Service and Office).

Seeing the phenomenon of the utilization gap between research results in policy formulation, it is necessary to communicate the research results with the policy. According to Sumarto, S. (2018), research and policy communication can be seen from the demand and supply side. First, the demand side is influenced by the evidence that research results are always used as a basis for policy making, research results are available and easily accessible. Evidence from research results is highly valued. Second, the supply side is influenced by relevant research carried out and communicated effectively, evidence of research results is properly understood, and research is designed and implemented to be relevant to policy.

To bridge the use of research into policy formulation, Hanney et.al (In Siswanto, 2007), have compiled a model for the use of research for policy that there is no direct impact from the results of research published in scientific journals on a policy, but it will only have an impact. on the abundance of knowledge available. Therefore, in order to increase the chances of using research results, both published and unpublished, policy makers and researchers are expected to build communication or discussion since the interface stage (a), which is to identify research topics / themes and research questions needed in accordance with developing strategic issues, 
322 Jurnal Ilmiah Ilmu Administrasi Publik: Jurnal Pemikiran dan Penelitian Administrasi Publik

Volume 10 Number 2, July-December 2020. Page 319-330

and the interface stage (b), namely the dissemination of research results in a policy forum that includes policy makers, and not just scientific seminars between researchers.

\section{METHOD}

This study used a qualitative descriptive. The focus of research in this paper is on the need for sources of knowledge, i.e. the Head of the Regional Border Management Agency of North Central Timor Regency (in Indonesian: Badan Pengelola Perbatasan Daerah Kabupaten Timor Tengah Utara) and the Heads of the Divisions at the Regional Border Management Agency of the North Central Timor Regency. Data were collected through interviews until they were saturated. The analysis method used in this research is interactive analysis with three components of analysis, namely data reduction, data presentation and drawing conclusions (Sugiyono, 2012).

\section{RESULT AND DISCUSSION}

The Role of Research Results in Policy Formulation at the Regional Border Management Agency of North Central Timor Regency

In the Regulation of the Minister of Home Affairs of the Republic of Indonesia No. 140/2017 concerning the establishment of the Regional Border Management Agency, article 12 points (a) and (b), it describes that the duties of the Regency/City Border Management Agency are to carry out the following functions: (a) compiling an action plan for the development of border areas and (b) setting programs and budget for the development of border areas based on the priority scale. Therefore, referring to those functions, the Regional Border Management Agency of North Central Timor Regency must compile a strategic plan document (in Indonesian: Rencana Strategis (Renstra)) for a period of 5 years, namely $2016-2021$, and a work plan (in Indonesian: Rencana Kerja (Renja)) annually.

Based on the provisions of laws and regulations, the Regional Border Management Agency is given the authority to prepare those documents. According to William Dunn, several stages in formulating public policy are as follows:

1. Formulation of the Problem.

According to Dunn, it can be said that the formulation of the problem will help to find out what problems to solve. The completion of a planning document (i.e. a strategic plan of the Border Management Agency of North Central Timor Regency for 2016 - 2021) is inseparable from the social gaps around border areas that require policy intervention for the development of border areas. Classic problems in border areas consist of inadequate infrastructures such as roads, bridges, electricity, clean water, education and health. Apart from that, economic problems and border conflicts must also be considered by the Central and Regional Governments. 
The Regional Border Management Agency of North Central Timor Regency in the Strategic Plan for 2016 - 2021 has identified strategic issues related to border management problems, namely as follows:

a. The limitation of community economic empowerment based on the regional superior potential that is environmentally friendly in a synergistic and sustainable manner;

b. The low quality of human resources in the development of quality, equitable, and accessible health and education;

c. The underdevelopment of infrastructure in border areas;

d. The limited availability and services of public transport which causes the high use of private vehicles; and

e. The lack of good and clean local governance.

The Strategic Plan (in Indonesian: Rencana Strategis (Renstra)) for 2016 - 2021 from the Regional Border Management Agency of North Central Timor Regency which has been approved is used further as a reference in formulating a work plan (in Indonesian: Rencana Kerja (Renja)) as an annual planning document that contains policies and programs for one year only.

In identifying strategic issues in the Strategic Plan and the Work Plan, it was conducted through a scientific activity to produc quality planning documents. In the provisions of laws and regulations, the stages of problem formulation include several activities, namely as follows:

a. Formulating the Regional Work Units (in Indonesian: Satuan Kerja Perangkat Daerah) vision and mission based on the vision, mission, and programs of the elected regional head;

b. Conducting strategic studies by the head of Regional Work Units to determine strategies in formulating a group of objectives and policies in achieving the Regional Work Units vision and mission based on their duties and functions. Those studies must use an analytical method that considers the external environment (elected Regional Head programs, the condition of the Regional Work Units affairs object, community support, etc.) and the internal environment (internal conditions of the Regional Work Units, human resources, equipment, policies, etc.). Those studies must also be complemented by the evaluation results of the Renstra of the Regional Border Management Agency of the North Central Timor Regency carried out by the Regional Work Units in the previous period; and

c. Reviewing the regional medium-term development plans (In Indonesia: Rencana Pembangunan Jangka Menengah Daerah) and the strategic plan that have been approved.

Based on the results of an interview with the Head of the Border Management Agency of North Central Timor Regency, Dra. Emmerentiana I. Ukat, on July 22, 2020, it indicates that in order to support the formulation of problems to determine the right policy, the Border Management Agency of North Central Timor Regency gathered information through the Development Planning Deliberation (in Indonesian: Musyawarah Perencanaan Pembangunan (Musrenbang)) in the levels of the village, sub-district, and regency. Furthermore, they also collected data from the field survey, the mass media, and published research results. It is as in the following interview excerpt: 


\section{4 | Jurnal Ilmiah Ilmu Administrasi Publik: Jurnal Pemikiran dan Penelitian Administrasi Publik \\ Volume 10 Number 2, July-December 2020. Page 319-330}

"In formulating problems to support the formulation of quality targeted policy and program, the Regional Border Management Agency of North Central Timor Regency is actively involved in the Musrenbang in the levels of the village, sub-district, and regency, conducts field surveys to map the potential and existing problems, responds to information from the mass media, and accesses the published research results".

This was strengthened by the statements from the Head of Border Management Division at the Regional Border Management Agency of North Central Timor Regency, Djibrael D. Pandie, SP He said as follows:

"The Regional Border Management Agency of North Central Timor Regency is given the authority to formulate policies, programs, and activities related to border management. For this reason, the Border Management Agency of North Central Timor Regency through several ways conducts activities to compile a strategic plan starting with reviewing the higher policies (Law, RPJMD from the regency government, and Renstra and Renja from ministries or other institutions), the supports from experts and academicians in terms of ideas in the research results, and other policy recommendations." (An interview on August 12, 2020).

\section{Policy Agenda}

Essentially, not all public issues will be discussed in the policy agenda. Those issues will compete with one another. Only certain issues end up on the policy agenda. One of the conditions for an issue to be discussed in the policy agenda is that it has a big impact on society and requires immediate action.

Based on Dunn's statement concerning the policy agenda stage, the government must attempt to formulate several important agendas that need to be discussed and then used as the main material for formulating public policies. Based on the researchers' observations in the field and the collected documents, the Regional Border Management Agency of North Central Timor Regency has prioritized handling problems in the border area. In the development plan document and the strategic plan document of the Regional Border Management Agency of North Central Timor Regency for 2016 - 2021, they have contained the development of border areas as a priority.

Furthermore, in the strategic plan document of the Regional Border Management Agency of North Central Timor Regency for 2016 - 2021, the Regional Border Management Agency of North Central Timor Regency has a vision, namely "Realizing the acceleration of the development of North Central Timor Regency as a well-planned, directed, integrated, and responsible area". From this vision, it is then developed in several missions, namely (1) improving the quality of apparatus resources, (2) accelerating infrastructure development in border areas, (3) improving security and order in border areas, and (4) improving the welfare and quality of human resources in border areas.

Based on the development and strategic document plant of the Regional Border Management Agency of North Central Timor Regency for 2016 - 2021, the objective for the implementation of border management activities can be seen in the following table. 
Table 2.

The Objective of Border Development Activities

\begin{tabular}{|c|c|c|c|c|c|}
\hline Objective & Targets & Indicators & 2019 & 2020 & 2021 \\
\hline \multirow{3}{*}{$\begin{array}{l}\text { Increasing the } \\
\text { development of } \\
\text { border areas }\end{array}$} & \multirow{3}{*}{$\begin{array}{l}\text { The developing } \\
\text { border areas }\end{array}$} & $\begin{array}{l}\text { The master plan document } \\
\text { for the development of } \\
\text { border areas }\end{array}$ & - & - & - \\
\hline & & $\begin{array}{c}\text { The length of the built } \\
\text { road }\end{array}$ & 60.75 & 71.75 & 81.75 \\
\hline & & $\begin{array}{c}\text { The number of built } \\
\text { bridges }\end{array}$ & 3 & 4 & 5 \\
\hline
\end{tabular}

Source: RPJMD Kab. TTU for 2016 - 2021

Furthermore, in the Renstra and Renja of the Regional Border Management Agency of North Central Timor Regency for 2016 - 2021, the Regional Border Management Agency of North Central Timor Regency has prioritized three areas of activity, namely infrastructure, partnership, and boundary management.

3. The Selection of Options to Solve Problems.

After the problem formulation and the preparation of the agenda have been completed, the selection of the alternative policies to solve the problem is conducted. At this stage, the draft of the strategic plan of the Regional Border Management Agency of North Central Timor Regency is refined to become the final draft. The first thing to do is to sharpen the vision and missions. The vision and missions of the Regional Border Management Agency of North Central Timor Regency which has been formulated are sharpened and adjusted to the vision and missions of the government in the development document plan and the Regional Regulation. This is important because these visions and missions will serve as a direction for the goals, objectives, strategies, policies, programs, and activities of the Regional Border Management Agency of North Central Timor Regency.

4. The Stage of Policy Determination.

The last stage in the policy formulation process based on Wiliam Dunn's theory of policy formulation is the determination of the policy. This stage needs to be carried out so that a policy that has been chosen in the previous stage will have the binding legal force and cannot be contested (in Antik Bintari, S.IP., M.T., Landrikus Hartarto Sampe Pandiangan, 2016). The Strategic Plan of the Regional Border Management Agency of North Central Timor Regency for 2016 - 2021 is determined through the Regulation of the Head of the Regional Border Management Agency of North Central Timor Regency.

Based on the data above, the results of this research concerning the formulation of border management policies by the Regional Border Management Agency of North Central Timor Regency have a very important role as input/information and policy recommendations for policy makers in formulating quality policies. 
326 Jurnal Ilmiah Ilmu Administrasi Publik: Jurnal Pemikiran dan Penelitian Administrasi

Volume 10 Number 2, July-December 2020. Page 319-330

\section{Constraints on Applying Research Results in Policy Formulation at the Regional Border Management Agency of North Central Timor Regency}

To be able to identify constraints in the use of research in the formulation of border management policies in the North Central Timor District Border Management Agency, the researchers conducted primary data collection and secondary data at the Regional Border Management Agency of North Central Timor Regency with the Head of the Regional Border Management Agency of North Central Timor Regency The Head of Division and staff as well as data taken from documents related to activities carried out by the Regional Border Management Agency of the North Central Timor Regency to support the quality of policy formulation, some preliminary information can be obtained including as shown in the table below.

Table 3.

Recapitulation Of Interview Results Held On July 22, 2020

Related To Research And Its Use

\begin{tabular}{c|l|l}
\multicolumn{1}{c}{ No } & \multicolumn{1}{c}{ Targets } & \multicolumn{1}{c}{ Indicators } \\
\hline 1 & $\begin{array}{l}\text { Forms of activities related to research } \\
\text { conducted by the Regional Border } \\
\text { Management Agency of North Central } \\
\text { Timor Regency }\end{array}$ & $\begin{array}{l}\text { The Head of the Border Management Agency } \\
\text { responded that the Regional Border } \\
\text { Management Agency of North Central Timor } \\
\text { Regency has carried out activities that can be } \\
\text { categorized as research, such as conducting } \\
\text { field observations/surveys and participating in } \\
\text { seminars and workshops. }\end{array}$ \\
\hline 2 & Number of Research Activities & $\begin{array}{l}\text { Activities related to research conducted } \\
\text { by the Regional Border Management } \\
\text { Agency of North Central Timor Regency } \\
\text { is still for a short-term need and is still } \\
\text { not centralized due to limited human } \\
\text { resources. }\end{array}$ \\
\hline 3 & $\begin{array}{l}\text { Collaboration with universities or other } \\
\text { It also varies depending on the urgency } \\
\text { of the needs and financial support. }\end{array}$ \\
\hline research groups & $\begin{array}{l}\text { Collaboration between the Regional } \\
\text { Border Management Agency of North } \\
\text { Central Timor Regency and universities } \\
\text { or other research institutions has already } \\
\text { been done, however, the number is still } \\
\text { relatively small. } \\
\text { Based on data during 2020, the Regional } \\
\text { Border Management Agency of North } \\
\text { Central Timor Regency was once invited } \\
\text { by the Faculty of Social and Political }\end{array}$ \\
\hline
\end{tabular}




\begin{tabular}{l|l|l}
\hline \multicolumn{1}{l}{ No } & \multicolumn{1}{c}{ Targets } & \multicolumn{1}{c}{ Indicators } \\
\hline & & $\begin{array}{l}\text { Sciences from the University of Timor to } \\
\text { participate in the dissemination of } \\
\text { research results in a national seminar on } \\
\text { the theme of developing border areas. } \\
\text { Moreover, there were 3 studies } \\
\text { conducted in 2019 and 1 study in 2020. }\end{array}$ \\
\hline 4 & $\begin{array}{l}\text { Information Utilization System for } \\
\text { products or research results by the } \\
\text { Regional Border Management Agency of } \\
\text { North Central Timor Regency }\end{array}$ & $\begin{array}{l}\text { The Regional Border Management Agency of } \\
\text { North Central Timor Regency highly } \\
\text { understands that the use of research } \\
\text { information is still very low so that it is } \\
\text { necessary to build a more intensive } \\
\text { communication framework through dialogue } \\
\text { or discussion regarding border management. }\end{array}$ \\
\hline
\end{tabular}

Source: Processed by Researchers (2020)

Based on the results of the interview on July 22, 2020, the researchers carried out a preliminary analysis. After that, the researchers then conducted an in-depth interview for the second meeting on August 12, 2020, with the leaders in the Regional Border Management Agency of North Central Timor Regency regarding the constraints on applying research results in policy formulation. The results from these interviews can be seen in the following table.

\section{Table 4.}

Recapitulation of Interview Results on August 12, 2020

\begin{tabular}{c|l|l}
\multicolumn{1}{c}{ No } & \multicolumn{1}{c}{ Types of Constraints } & \multicolumn{1}{c}{ Responses } \\
\hline 1 & Communication Strategy & $\begin{array}{l}\text { Evidence in the form of research results } \\
\text { from universities or researchers should } \\
\text { be communicated on an advocacy basis } \\
\text { in which researchers convey their } \\
\text { research results in dissemination and } \\
\text { intensive discussions as policy } \\
\text { recommendations. } \\
\text { Research results should be well- } \\
\text { established so that they seem in line with } \\
\text { the content of the policymakers' } \\
\text { interests. }\end{array}$ \\
\hline 2 & Human Resource & $\begin{array}{l}\text { Human resources in the Regional Border } \\
\text { Management Agency of North Central } \\
\text { Timor Regency are very lacking. This is } \\
\text { evidenced by the fact that several fields / } \\
\text { affairs are empty, so that the effect of } \\
\text { policy formulation is prioritizing } \\
\text { experience, rather than research results }\end{array}$ \\
\hline
\end{tabular}


328 Jurnal Ilmiah Ilmu Administrasi Publik: Jurnal Pemikiran dan Penelitian Administrasi Publik

Volume 10 Number 2, July-December 2020. Page 319-330

\begin{tabular}{|c|c|c|}
\hline No & Types of Constraints & Responses \\
\hline & & $\begin{array}{l}\text { because of the attitude of skepticism } \\
\text { towards the research results. } \\
\text { The lack of human resources in the North } \\
\text { Central Timor Regency Regional Border } \\
\text { Management Agency then affects the } \\
\text { work mechanism, the way of working, } \\
\text { which requires several people to have } \\
\text { concurrent positions or concurrent duties } \\
\text { in order to streamline the duties and } \\
\text { authority of the Regional Border } \\
\text { Management Agency of the North } \\
\text { Central Timor Regency }\end{array}$ \\
\hline 3 & Availability of Research Results & $\begin{array}{l}\text { The research results related to the } \\
\text { development of border areas are quite } \\
\text { easy to obtain on the internet. However, } \\
\text { the existing research results are not } \\
\text { always in line with the program or policy } \\
\text { being developed. } \\
\text { Many researchers whose research is } \\
\text { approved by the Regional Border } \\
\text { Management Agency of North Central } \\
\text { Timor Regency or those who conduct } \\
\text { research related to border management } \\
\text { do not submit their research reports to the } \\
\text { Regional Border Management Agency of } \\
\text { North Central Timor Regency. }\end{array}$ \\
\hline
\end{tabular}

Source: Processed by Researchers (2020)

Based on the data obtained above, it can be described that the constraints in the use of research by the Regional Border Management Agency of the North Central Timor Regency are generally influenced by the process of communicating policies and policy makers that are not yet optimal. In addition, strengthening management related to the post-research management system must also be considered as well as limited human resource constraints. 


\section{CONCLUSION}

From the results of this study, it indicated that the role of research results began to get attention at the stage of problem formulation in the Regional Border Management Agency of North Central Timor Regency as input or source of policy information to identify strategic issues related to border management in North Central Timor Regency. However, the use of research results in the formulation of policies has not been maximized. It was because of as follows. (a) Human resources in the Regional Border Management Agency of North Central Timor Regency are very lacking. This is evidenced by the fact that several fields / affairs are empty, so that the effect of policy formulation is prioritizing experience, rather than research results because of the attitude of skepticism towards the research results, (b) Research that is communicated effectively in the form of advocacy is conveyed by researchers through dissemination and intensive discussions as policy recommendations; and some researchers whose research is approved by the Regional Border Management Agency of North Central Timor Regency do not submit their research reports.

\section{REFERENCES}

Dunn, W. N. (2003). Pengantar Analisis Kebijakan Publik (Kedua ed.). Yogyakarta: GadjahMada University Press.

Jones, C. O. (1994). Pengantar Kebijakan publik. (N. Budiman, Penyunt., \& R. Istamto, Penerj.) Jakarta: Raja gravindo persada.

Peraturan Bupati Timor Tengah Utara Nomor 3 tahun 2019 tentang Pembentukan Badan Penegelola Perbatasan Daerah Kabupaten Timor Tengah Utara.

Peraturan Menteri Dalam Negeri Republik Indonesia nomor 140 tahun 2017 tentang pembentukan Badan Pengelola Perbatasan Daerah.

Peraturan Menteri Riset, Teknologi, dan Pendidikan Tinggi Nomor 20 Tahun 2008 tentang Penelitian.

Sadhana, K. (2011). Realitas Kebijakan Publik. Malang: Penerbit Universitas Negeri Malang.

Siswanto (2007). Peran Riset di Bidang Sistem dan Kebijakan Kesehatan dalam Pembangunan Kesehatan. Editorial Manajemen Kedokteran Indonesia, Volume 57, Nomor 3, Maret 2007.

Sundari, S. (2007). Menerjemahkan Hasil Penelitian Kedalam Kebijakan dan Pelayanan Kesehatan. Buletin Penelitian Kesehatan, Vol. 35, No. 4 
330 | Jurnal Ilmiah Ilmu Administrasi Publik: Jurnal Pemikiran dan Penelitian Administrasi Publik

Volume 10 Number 2, July-December 2020. Page 319-330

Sugiyono. (2014). Metode penelitian kuantitatif, kualitatif dan R\&D. Bandung: Alfabeta

Sumarto, S. (2018). Kebijakan Berbasis Bukti untuk Mendukung Pembangunan Inklusi. Materi Seminar NasionalLembaga Penelitian SMERU.

Wahab, S. A. (2014). Analisis kebijakan: dari formulasi ke penyusunan model- model implementasi kebijakan publik.Cet.2. Jakarta: Bumi aksara.

Winarno B. (2014). Kebijakan publik: teori, proses, dan studi kasus. Yogyakarta: CAPS (Center of Academic Publishing Service). 